\title{
Impact Assessment of Nerica Rice Production in Southwestern Nigeria
}

\author{
Apata, O.M., A. Awoyemi, A.A. Babayemi \\ Department of Agricultural Economics and Extension Services, Nigeria
}

Copyright $(2016$ by authors, all rights reserved. Authors agree that this article remains permanently open access under the terms of the Creative Commons Attribution License 4.0 International License

\begin{abstract}
Nigeria has a population of about 150 million people, which increases annually. This makes her rank among the fastest growing population in the world. Rice is the most staple food for Nigerians and most people all over the world. There is a huge competition for rice consumption. In recent years, rice production has been expanding at the rate of $6 \%$ per annum in Nigeria. With 70 percent of the production increase been attributed to land expansion and only 30 percent been attributed to increase in productivity. The New Rice for Africa (NERICA) was specifically bred by scientist of West Africa Rice Centre (WARDA)) to address the problem of low productivity of upland rice in Sub-saharan Africa. It was introduced to Nigeria in 2002 and the rice has unique characteristics such as shorter duration, high yields, tolerant to major stress, higher protein and good taste compare to the traditional rice varieties. The study was carried out to evaluate farmers' adoption of NERICA rice production and its impact on productivity of upland rice. Purposive sampling procedure was used to select 120 respondents for the study. The socio-economic characteristics and perceived constraints to increase productivity were ascertained using descriptive statistics to analyse the data. The effect of attitude on productivity was also derived in the course of the study. The result showed that NERICA has a high yield compared to other form of varieties with a significant value of $1 \%$ and $t$-value of 2.065 . The Pearson product moment correlation analysis shows that the coefficient between productivity (income) and attitude of respondents towards NERICA is 0.661 at a significant value of $0.000(1 \%)$.
\end{abstract}

Keywords New Rice for Africa, Productivity, Food Security, Poverty Alleviation

\section{Introduction}

Nigeria has a population of over 140 million people [1] in which domestic economy is partly determined by agriculture, which account for about $40 \%$ and the gross domestic products (GDP) and two-third of the labour force [2]. The country is currently pre-occupied with the challenge of diversifying the structure of its economy. The issue of poverty reduction strategy processes (PRSP) has been at the centre-stage of development programme. Nigeria government is more eager than ever to move its populace out of poverty by ensuring that there is food security. Since there is a belief that once the issue of food security is resolved, poverty is almost eradicated.

Rice is a staple food in Nigeria and constitutes major raw materials in agro-allied industries [3]. In recent years, rice production has been expanding at the rate of $6 \%$ per annum in Nigeria with $70 \%$ of the production increase due to land expansion and only $30 \%$ being attributed to an increase in productivity ([4],[5], [6], [7]).

Notwithstanding, the demand for rice is growing faster than production in the country, thus making the country depend on imported rice to meet the high demand. [8] reported that the bulk supply of rice in Nigeria comes mainly from importation and indicated that food imported still accounts for $11.4 \%$ of food consumed in Nigeria. The short fall in domestic rice production necessitated its importation in large volume which constituted an enormous drain on the country's foreign exchange reserve

Several factors have been attributed to the slow bridge in the demand and supply gap. Prominent among which are the fact that nearly half of Nigeria's 140 million people live below poverty line [9], the lack of high yielding varieties with good grain qualities, competition with imported rice and inadequate post-harvest technologies.

New Rice for Africa (NERICA) was specifically bred by Scientists of Africa Rice Centre (WARDA) to address the problem of low productivity of upland rice in Sub-sahara Africa. It has unique characteristics such as shorter duration (mature between 30 and 50 days earlier than traditional varieties), higher yield, tolerant to major stress, higher protein, good taste, stable yield under different condition compared with the traditional rice varieties ([10], [11], [12], [13].

NERICA was introduced to Nigeria rice farming system through multinational NERICA Rice dissemination project 
which was launched in 2002. In 2003 Nigeria enthusiastically adopted [14]. The study was developed to compare the productivity of NERICA rice with the local variety in order to ascertain the impact of the new rice on rice production in the zone. The study was designed to examine the socio-economic characteristics of the respondents, rice production in the zone, attitude towards NERICA rice production and the perceived constraints to rice production in the zone..

\section{Methodology}

The research was conducted in south western Nigeria. The south western region lies between $3^{0} \mathrm{Ek}$ and $6^{\circ} \mathrm{E}$ of the longitude and also between $6^{0} \mathrm{~N}$ and $9^{0} \mathrm{~N}$ of the latitude. It is the second largest population of the geopolitical zone of the country. The south western region has an estimated population of about 50 million people.

Purposive sampling procedure was employed in selecting two states Ondo and Ekiti States as they are the only states in south-western Nigeria that participated in NERICA phase 1. Purposive sampling procedure was also used to select two Local Government Areas that participated in NERICA phase 1 from the two states. 30 NERICA farmers and 30 Non-NERICA farmers were purposively selected from each Local Government Area making a total of 120 respondents for the study.

Both primary and secondary data were used. Primary data was collected with the aid of a well-structured questionnaire, open discussion; interview and physical observations were also used. The interview schedule contained both open and closed ended questions which were good enough to justify the objective of the study. Secondary data was collected mainly from literatures of past researches, journal and text-books.

The statistical tools employed include; descriptive analysis, student t-test analysis and regression analysis. The descriptive analysis was used to analyze and describe the socio-economic characteristics of the respondents and perceived constraints to rice production. The impact of NERICA on farmers' productivity was ascertained using the t-test analysis.

\section{Results and Discussion}

\section{Socio-Economic Characteristics of the Respondents}

Mean age of the respondent is 46.9 years with standard deviation of 11.14. From Table 1, age bracket 51 to 60years formed the 31.40 percent of majority of the farmers which is closely followed by the age bracket of 41 to 50 years which is about $30.1 \%$ of the total respondents. This implies that the respondents are in their active age of less than 60 years and still actively in involve in rice production. He female respondents form $23.3 \%$, while the male respondents form $76.7 \%$, this shows that both sexes are adequately represented in the study. Also from Table 1 that the most households have family size between 5 and 9 , this infers that labour should not be a constraint as most farming households depend majorly on family labour. The Table further showed that 25.5 percent of the respondents had no formal education with about 9.2 percent having post-secondary education, this implies that majority of respondents can understand language used on radio and some can understand print information such as handbills, billboard and newspaper.

Table 1. Distribution of Respondents by their Socio-economic Characteristics

\begin{tabular}{|c|c|c|}
\hline Variables & Frequency & Percentage \\
\hline \multicolumn{3}{|l|}{ Age (Years) } \\
\hline$\leq 30$ & 13 & 10.8 \\
\hline $31-40$ & 21 & 17.3 \\
\hline $41-50$ & 36 & 30.1 \\
\hline $51-60$ & 38 & 31.4 \\
\hline$>60$ & 12 & 9.8 \\
\hline \multicolumn{3}{|l|}{ Gender } \\
\hline Male & 92 & 76.7 \\
\hline Female & 28 & 23.3 \\
\hline \multicolumn{3}{|l|}{ Marital Status } \\
\hline Single & 14 & 11.7 \\
\hline Married & 103 & 85.8 \\
\hline Divorced & 13 & 2.5 \\
\hline \multicolumn{3}{|l|}{ Family Size } \\
\hline $1-4$ & 42 & 35 \\
\hline $5-9$ & 59 & 49.1 \\
\hline$\geq 10$ & 19 & 15.9 \\
\hline \multicolumn{3}{|l|}{ Level of Education } \\
\hline No formal education & 31 & 25.8 \\
\hline Primary & 40 & 33.8 \\
\hline Secondary & 38 & 31.7 \\
\hline Tertiary & 11 & 9.2 \\
\hline
\end{tabular}

Source: Field Survey, 2012

\section{Frequency Distribution of Attitude towards NERICA Rice among Respondents}

From Table 2 below attitude of respondents towards NERICA Rice production was analyzed and there was compares between NERICA farmers and non-NERICA farmers. About $78.0 \%$ of NERICA farmers and $33.3 \%$ of non-NERICA rice farmers have favourable attitude towards NERICA rice production. On the other hand, $66.7 \%$ of non-NERICA rice farmers and $21.7 \%$ of NERICA farmers have unfavourable attitudes towards NERICA rice production. This finding may be due to the fact that most of non-NERICA farmers do not have enough information about NERICA rice since they were not involved in the production. This implies that more campaign should be made about 
NERICA rice among rice farmers in the zone so that this will improve farmers' attitude towards the rice production

Table 2. Frequency Distribution of Farmers' Attitude towards NERICA Rice

\begin{tabular}{|c|c|c|}
\hline ATTITUDE & $\begin{array}{c}\text { NERICA } \\
\text { FARMERS }\end{array}$ & $\begin{array}{c}\text { NON-NERICA } \\
\text { FARMERS }\end{array}$ \\
\hline Favorable & $47(78.3)$ & $20(33.3)$ \\
\hline Unfavorable & $13(21.7)$ & $40(66.7)$ \\
\hline TOTAL & $60(100.0)$ & $60(100.0)$ \\
\hline
\end{tabular}

Source: Field Survey, 2012

\section{Respondents' Medium of Awareness of NERICA Rice}

Table 3; shows that $50.0 \%$ of respondents indicated that their medium of awareness is majorly attributed to friends followed by extension services $(45.0 \%)$. Electronic media only accounted for $5.0 \%$ of the respondents. This implies that there is need to promote agricultural information dissemination among electronic media. This Table also shows that majority of the respondents $(69.2 \%)$ are of the opinion that the quality of grain size of NERICA is of high quality compared with the local varieties. This also implies that if there is adequate information about NERICA rice farmers will adopt it.

Table 3. Medium of Awareness and Preference of NERICA to Local Rice

\begin{tabular}{ccc}
\hline Variables & Frequency & Percentage \\
\hline Medium of awareness & 60 & 50.0 \\
Friend & 50 & 45.0 \\
Extension & 6 & 5.0 \\
Advertisement & & \\
Preference for NERICA & 83 & 69.2 \\
Preferred NERICA to other varieties & 37 & 30.8 \\
Preferred other varieties to NERICA & & \\
\hline
\end{tabular}

Source: Field Survey, 2012

\section{Analysis of Constraints to Rice Production}

Table 4 shows the constraints to increase productivity; one of the constraints is inaccessibility to extension services as about 58.3 percent of the respondents indicated that they do not have access to adequate extension services. This implies that majority do not have access to information that can enhance their productivity. Also, 84.2 percent of the respondents indicated the problem of pest infestation and disease infection as major cause of decline in their productivity. The half of the respondents $(50.8 \%)$ claimed that lack of access to credit facilities is their constraint to increased productivity. As shown in the Table, harvesting $(20.0 \%)$, storage $(25.8 \%)$ and weed $(20.8 \%)$ are also regarded constraints to increased rice production.
Table 4. Frequency Distribution of constraints to Rice Production

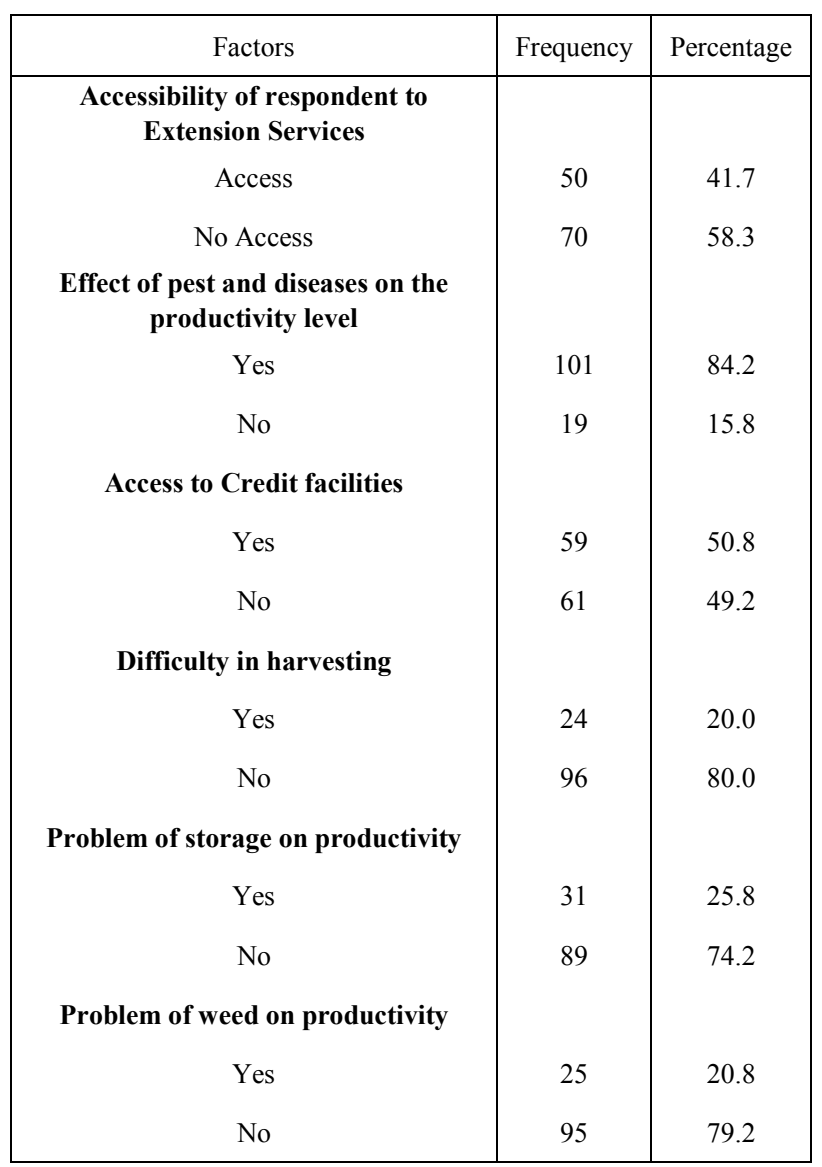

Source: Field Survey, 2012

\section{Analysis of Rice Production among Farmers}

This section tries to interpret the result of the t-test analysis that was used to test whether there is a significant difference in productivity of NERICA and NON-NERICA farmers. The result of the $t$-test shows that the $t$-value is 2.065 at level of significance of $1 \%$. This shows that the productivity of NERICA farmers is greater than the NON-NERICA farmers. Consequently there is significant difference between NERICA rice and local rice production. Therefore there is positive impact of NERICA rice on rice production in the zone hence in Nigeria. This implies that if all rice farmers can adopt NERICA rice production; there will be increase in rice production in the zone and the country. This will lead to food security in the country.

\section{Conclusions}

There is no gainsaying to the fact that adoption of NERICA rice has immense impacts on the productivity of rice farmers. NERICA rice production increases the level of income and standard of living of farmers as well as providing self-sufficiency in rice production. This has been a major focus of food policy goal of Nigerian Government in the last two decades of achieving food security. Therefore, NERICA rice production should be encouraged among farmers. 


\section{Recommendation}

Based on this study the government of this country should try to create more awareness on production of NERICA rice among farmers especially the rice farmers through extension agents and also give them non-formal and formal education on the production of NERICA rice and its advantaged over other local varieties. Government should provide credit facilities, research should be designed to combat pest and disease which can reduce the productivity of NERICA rice. Also, Government should provide modern rice processing equipment where there will be threshing, parboiling and milling of rice in an hygienically way with less wastage.

\section{REFERENCES}

[1] National Population Commission Report 2006

[2] NBS, \{2007\}. National Bureau of Statistics Annual Report.

[3] Adesuyi; S.A. $\{1997\}$ : "Preservation of grains in the tropical with special references to Nigeria. Applied Tropical Agricultural Journals 20 (2). 35

[4] Fagade, S. O $\{2000\}$. Yield Gaps and Productivity Decline in Rice Production in Nigeria at the Expert Consultation on Yield Gap and Production Decline in Rice, 5-7 September, 2000. FAO, Rome Italy. $15 \mathrm{pp}$

[5] Falusi, A.O. $\{1997\}$.Agricultural Development and Food production in Nigeria: Problems and Prospects. In: B. Shaid N. O., Adedipe, M. Aliyu and J. R, M. \{eds\} Integrated Agricultural Production in Nigeria: Strategy and Mechanism \{NARP\} Monograph No 5pp 151-170.
[6] African Rice Centre \{WARDA][2007]. African Rice Trends: Overview of Recent Development in the Sub- Saharan Africa Rice Sector, Africa Rice Center Brief Cotonou Benin, WARDA 8pp

[7] Okoruwa V. O., M. A. Y. Rahji and O, Ajani, $\{2007\}$ Rice and Maize Stratification Project in Nigeria. Draft Report.

[8] Adekanye T. O \{1998\} "Marketing for food; Problem and Prospectus for Rural Development in Nigeria" in Adekanye T. $\mathrm{O}$ ed reading in Agricultural Marketing Longman Nigeria pg 29.

[9] NBS, $\{2005\}$. National Bureau of Statistics Annual Report.

[10] Jones M.P., M., Dingkuhn, D. E, Johnson, and Sam o. Fagade. $\{1997\}$.Interspecific hybridization: progress and prospect proceedings of the workshop: Africa/Asia Joint Research, Interspecific Hybridization between Africa and Asia Rice Species ed. \{Oryza glaberrima and Oryza sativa\}.Bouake: WARDA.

[11] DingKuhn, M.; P. J., Monty; D.E. Johnson and Sow $\{1998\}$ Growth and Yield Potential of Oryza Sativa and O. Glaberrima Upland Rice Cultivars and Their Interspecific Pogenies. "Field Crops Research 57, no.1:57- 59

[12] Auderbert, A.; M., Dingkuhn; J.P. Monty and David E. J.[1998]. Physiological Mechanism for Vegetative Vigor of Interspecific upland rice-implications for weed competitiveness. Japanese Journal of Cop Sciences $67\{2\}$ : 358-59.

[13] Wopereis, M.C S.; A. D. Diange, J. Rodenburg; M. Sie and E. A. Somado. \{2008.\}." Why NERICA is a successful innovation for Africa farmers: A response to Orr et al from the Africa Rice Centre Outlook on Agriculture, Vol. 37, No. 3.pp. 169-176.

[14] Rice Centre \{WARDA\}, 2005. Rice Trends in Sub- Saharan Africa Third Edition, Cotonou, p. 31. 